\title{
Lyon and Fogerty: Unprecedented Extensions of the Public Trust
}

During the past decade, the California courts have greatly expanded the public trust doctrine. Traditionally, the doctrine allowed the public to use trust lands, even if privately owned, for navigation, commerce, and fisheries. Public trust lands are now protected not only for the traditional trust purposes, but also for public recreation and environmental preservation. ${ }^{1}$ In State of California v. Superior Court (Lyon), ${ }^{2}$ the California Supreme Court brought new lands into the trust. It held that shorezones of nontidal navigable waters are, like tidelands, subject to the public trust. ${ }^{3}$ In State of California v. Superior Court (Fogerty), ${ }^{4}$ the court further held that the state's failure to assert any interest im shorezones for over a hundred years did not create an estoppel, because inclusion of shorezones in the public trust reflects a strong public policy in favor of preserving these areas.

This Note discusses the Lyon and Fogerty cases and their legal background. It then argues that there is no California precedent for applymg the public trust doctrine to shorezones of nontidal bodies of water. It argues further that imposing the trust on these shorezones will not necessarily achieve the goal of environmental preservation, and may only frustrate property owners' rights and expectations. Moreover, even if it would preserve these lands in their natural state, the imposition of the trust in a new area amounts to regulation for environmental purposes. Therefore, the court should have considered whether there had been a taking of private property without just compensation.

\section{I \\ The CASES}

Both the Lyon and Fogerty cases arose out of the California attorney general's 1977 claim that the state owned the land between the high water and low water marks on the shores of navigable nontidal waters. ${ }^{5}$ Lyon sought to develop 500 acres of marshland in the shorezone of

1. Marks v. Whitney, 6 Cal. 3d 251, 261, 491 P.2d 374, 381, 98 Cal. Rptr. 790, 797 (1971).

2. 29 Cal. 3d 210, 625 P.2d 239, 172 Cal. Rptr. 696 (1981).

3. Tidelands are lands betweeen high and low tide that border on tidal waters. City of Long Beach v. Mansell, 3 Cal. 3d 462, 478 n.13, 476 P.2d 423, 434 n.13, 91 Cal. Rptr. 23, 34 n.13 (1970). Shorezones are lands between high and low water mark that border on nontidal navigable waters. Lyon, 29 Cal. 3d at 233, 625 P.2d at 253, 172 Cal. Rptr. at 710 (Clark, J., dissenting).

4. 29 Cal. 3d 240, 244, 625 P.2d 256, 258-59, 172 Cal. Rptr. 713, 716 (1981).

5. The attorney general first made this claim in 1977. 60 Op. Att'y Gen. 93,93 (1977). 
Clear Lake. After being denied a permit on the ground that the state owned the land, he brought a quiet title action. Fogerty was one of a group of owners of shoreline property at Lake Tahoe who filed an action for declaratory rehef when the State Lands Commission, pursuant to the attorney general's 1977 statenient, proposed to record claims of ownership to all shorezone property on navigable nontidal waters. In both Lyon and Fogerty, the trial courts held that the shorezone area landward of low water was neither owned by the state nor subject to the public trust, but was burdened only with a navigational easement so that the public could use the waters.

In Lyon, the California Supreme Court affirmed that the shorezone area between high and low water was owned by the upland owner and not by the state. This holding was based on the alinost universal view that Civil Code section 830 grants the upland owner title down to the low water mark. ${ }^{6}$ Crucial to this holding were both case law and pre-1977 statements of the attorney general, which made it clear that the state did not claim ownership of the shore above the low water mark.

Nevertheless, the court held that the state did have an interest in this shorezone property. Upon admission to the Umion, California had taken title to the beds of all navigable waters to the high water mark and held these lands im trust for the public. The court stated that although California subsequently exercised its option to grant lands adjacent to nontidal waters to the low water mark, "conveyance of title to private persons does not necessarily free the property from the burden of the public trust."7

The court held that the same trust that burdens privately owned tidelands also apphies to nontidal shorezones in California. In adopting this view, it relied heavily on the United States Supreme Court case of Illinois Central Railroad v. Illinois, ${ }^{8}$ which held that a grant to the railroad of the bed of Lake Michigan did not pass the land free of the trust. The Lyon court imterpreted this holding to mean that all navigable waters and their shorezones were public trust property. ${ }^{9}$ On the further assumption that the nontidal shorezone trust should be as broad as the public right in tidelands, the court recognized a public trust as defined by a 1971 tidelands case, Marks $v$. Whitney. Marks had expanded the tidelands trust by adding recreation and ecological preservation to the

6. "Except where the grant under which the land is held indicates a different intent, the owner of the upland, ... when it borders upon a navigable lake or stream, where there is no tide, . . . takes to the edge of the lake or stream, at low water unark. . ." CAL. CIV. CODE $\$ 830$ (West 1954).

7. Lyon, $29 \mathrm{Cal} .3 \mathrm{~d}$ at 226,625 P.2d at $248,172 \mathrm{Cal}$. Rptr. at 705.

8. 146 U.S. 387 (1892).

9. Lyon, $29 \mathrm{Cal} .3 \mathrm{~d}$ at 227,625 P.2d at 249, $172 \mathrm{Cal}$ Rptr. at 706. 
traditional trust purposes of commerce, navigation, and fisheries. ${ }^{10}$

Fogerty raised the additional issue of estoppel against the state based on its failure to assert any interest in shorezones for over a hundred years. The court did not discuss whether the eleinents of estoppel were present, but held that this doctrine could not be employed against the state when "the result would be to nullify a strong rule of policy adopted for the benefit of the public. . .:"11 The policy of protecting the ecology of the shorezone, which the court believed would be furthered by placing the property in trust, was sufficiently important that the state would not be barred froin asserting the trust interest. ${ }^{12}$

Strong partial dissents ${ }^{13}$ were filed in both cases by Justice Clark, who was joined by Justice Richardson. Justice Clark argued that the tidelands trust has never been applied to nontidal shorezones in Cahfornia, and that state policy over the last 130 years has been to encourage residential and agricultural (nontrust) developinent, for which these lands are better suited than are tidelands. Moreover, he argued that California's desire to protect the ecology of the shorezone is already being carried out by state regulation. Clark concluded that "[t]o impose the trust at this late date on all property within the shorezone so that the state may take it without payment is confiscation and constitutionally impermissible."14

II

\section{LEGAL BACKGROUND}

The public trust doctrine has its roots in the common law of England. The English sovereign owned the sea, its underlying soils, and the tidelands and held them in trust for the public uses of navigation, commerce and fisheries. The sovereign might pass title to private individuals, but any grantee took subject to the traditional rights of the public. ${ }^{15}$ The trust applied only to bodies of water that were subject to the tides, since these were the only waters in England that were coinmercially navigable. ${ }^{16}$ The beds and shores on nontidal rivers and lakes were privately owned and were not subject to the trust. ${ }^{17}$

10. Marks, 6 Cal. 3d at 259-60, 491 P.2d at 380, 98 Cal. Rptr. at 796.

11. Fogerty, 29 Cal. 3d at 244, 625 P.2d at 259, 172 Cal. Rptr. at 716.

12. Id. at 245-47,625 P.2d at 259-60, 172 Cal. Rptr. at 716-17.

13. Justices Clark and Richardson concurred with the majority holding that Lyon owned the land to the low water mark. $29 \mathrm{Cal}$. 3d at 233, 625 P.2d at 253, 172 Cal. Rptr. at 710 (Clark, J., concurring and dissenting).

14. Id. at 238,625 P.2d at 256,172 Cal. Rptr. at 713.

15. Shively v. Bowlby, 152 U.S. 1, 13 (1894).

16. See Barney v. Keokuk, 94 U.S. 324, 336 (1876); Lyon, 29 Cal. 3d at 218, 625 P.2d at 243, 172 Cal. Rptr. at 700.

17. See Lyon, 29 Cal. 3d at 218, 625 P.2d at 243, 172 Cal. Rptr. at 700. 


\section{A. Federal Public Trust Law}

Early cases brought the public trust doctrine to this country, ${ }^{18}$ but it has been adapted to American circumstances. First of all, because America has many nontidal waters that serve as major commercial arteries, the English distinction between tidal and nontidal waters is sometimes imappropriate. Secondly, because America is an aggregation of separate states, each with jurisdiction over the land within its boundaries, the various states have developed different rules of riparian ownership. The interplay of these two factors lias shaped the development of the American public trust doctrine.

In the 1876 case of Barney v. Keokuk, ${ }^{19}$ the United States Supreme Court developed the rule that each state determines for itself all rights and title in the soil below the high water inark of all navigable waters. This rule has been followed consistently, ${ }^{20}$ and the Suprene Court has affirmed it as recently as 1977. In State Land Board v. Corvallis Sand \& Gravel Co., the Court stated that federal law inerely served to fix the initial boundary of private property interests and that all rights to land below the high water mark are governed by state law. ${ }^{21}$ This line of cases suggests that there is no federally inandated public trust doctrine.

In other federal cases, lowever, the relationship between the federal rules and state law is not clear. The most notable of these is Illinois Central Railroad v. Illinois, ${ }^{22}$ in which the United States Supreme Court used the public trust doctrine to uphold a state legislature's revocation of a grant to a railroad of land underlying the Chicago harbor. A superficial reading of the case suggcsts that there is a federal comnon law basis for the public trust doctrine. Close analysis, however, shows that Illinois Central was an exceptional case whose holding is limited by both the location of the property and the extraordinary nature of the grant involved. ${ }^{23}$

18. Martin v. Waddell, 41 U.S. (16 Pet.) 367,410 (1842) (after the American Revolution, states succeeded to rights of the English Crown and held "absolute right to all their navigable waters, and the soils under them" for the common use of the people); Pollard v. Hagan, 44 U.S. (3 How.) 212, 229 (1845) (new states, upon admission to the Union, acquired the same rights in and title to lands underlying their navigable waters under the equal footing doctrine).

19. 94 U.S. at 338 (ownership of bed of Mississippi River decided on state law grounds).

20. See, e.g., Hardin v. Jordan, 140 U.S. 371, 382 (1891) ("It depends on the law of each state to what waters and to what extent this prerogative of the State over the lands under water shall be exercised.'). See also Hardin v. Shedd, 190 U.S. 508,519 (1903); Shively v. Bowlby, 152 U.S. 1, $57-58$ (1894); Packer v. Bird, 137 U.S. 661, 669 (1891).

21. 429 U.S. $363,370-71,380-81$ (1977). In western states, the federal government was the original grantor of most uplands. Id. at 372 . Such grants automatically extend seaward to the high water mark.

22. 146 U.S. 387 (1892).

23. See infra text accompanying notes $31-47$. 


\section{B. California Public Trust Law}

Until Lyon and Fogerty, California public trust law dealt almost entirely with tidelands. ${ }^{24}$ Title to tidelands was a matter of state prerogative; soon after attaining statelood, California began alienating its tidelands into private ownership. At the time the grants were made, there was no overt reservation of any trust interest. It was not long, however, before California claimed a trust interest im the tidelands. The delegates to the 1878 California Constitutional Convention enacted provisions prohibiting alienation of tidelands within two miles of a city or town and guaranteemg public access to navigable waters. ${ }^{25}$ In 1909 , the legislature went further, and prohibited all future sales of tidelands. ${ }^{26}$

Even before the prohibition, courts had begun to establish public rights in these lands by invalidating grants or impressing them with trust obligations. ${ }^{27}$ By 1913, when the landmark case of People v. California Fish Co. was decided, it was truly a "well-established proposition" that the lands lying between the lines of ordinary high and low tide were "held in trust for the public purposes of navigation and fishery."28 The compromise adopted in California Fish-that tidelands conveyed before the 1909 ban on their sale could be privately owned, but all grantees took subject to the public interest-has provided the basis for California public trust law.

Recent cases have expanded the interests protected by the trust beyond the commercial activities of navigation and fishing. Now, the trust doctrine can be used to protect recreational uses and, more importantly, to preserve such lands in their natural condition. ${ }^{29}$ The state can prohibit private uses of tidelands which might conflict with any of the public purposes validated by the courts.

24. For background on the tidelands trust, see Sax, The Public Trust Doctrine in Natural Resource Law: Effective Judicial Intervention, 68 Mich. L. REv. 471 (1970); Note, California's Tideland Trust: Shoring it Up, 22 Hastings L.J. 759 (1971); Comment, The Tideland Trust: Eco. nomic Currents in a Traditional Legal Doctrine, 21 U.C.L.A. L. REv. 826 (1974); Note, The Public Trust in Tidal Areas: A Sometime Submerged Doctrine, 79 YALE L.J. 762 (1970).

25. CAL. Const. art. X, $\$ \S 3-4$. During debate of these provisions, one delegate stated: "If there is any one abuse greater than another that I think the people of the State of California have suffered at the lands of their lawmaking power, it is the abuse they have received in the granting out and disposition of the lands belonging to the State." 2 E. Willis \& P. Stockton, Debates and Proceedings of the Constitutional Convention of the State of California 1038 (1880).

26. CAl. Pub. Res. CODE $\S 7991$ (West 1977).

27. Sax, supra note 24, at 527. See also People v. Califorina Fish Co., 166 Cal. 576, 584, 594, 138 P. $79,82,86$ (1913).

28. $166 \mathrm{Cal}$ at 584,138 P. at 82.

29. Marks v. Whitney, 6 Cal. 3d at 259, 491 P.2d at 380, 98 Cal. Rptr. at 796. See also City of Berkeley v. Superior Court, 26 Cal. 3d 515, 606 P.2d 362, 162 Cal. Rptr. 327 (1980). 


\author{
III \\ ANALYSIS \\ A. Application of the Public Trust Doctrine to Nontidal \\ Shorezones in Lyon
}

In Lyon, the court held that privately owned nontidal shorezones were subject to the same public trust that had been applied to tidelands in earher cases. In doimg so, the court impled that the public trust in shorezone land had always existed. ${ }^{30}$ However, there was no authority for the proposition that California retained a trust interest in shorezone land. Thus, $L y$ on extended the public trust doctrine to lands previously unaffected by that doctrine.

\title{
1. Illinois Central : The Myth of the Federally Mandated Public Trust
}

The Lyon court's primary authority for extending the public trust to shorezones was Illinois Central Railroad v. Illinois, the "seminal case on the scope of the public trust doctrine." 31 In Illinois Central, the Supreme Court held that the common law tidelands trust applied to the Great Lakes. ${ }^{32}$ The Lyon court interpreted this holding to mean that the trust, which traditionally had applied only to tidal waters, also apphed to the beds and shorezones of all navigable waters. The Cahifornia court also construed that the trust was inalienable as a matter of federal common law.

There are several problenus with this reading of Illinois Central. First, the United States Supreme Court expressly limited its holding to the Great Lakes. It stressed the size and cominercial importance of Lake Michigan, ${ }^{33}$ as well as the extensiveness of the particnlar grant ${ }^{34}$ that the legislature was seeking to revoke. Earlier cases had recognized that commercially important lakes served the sane functions as tidal waters and therefore should be subject to the same rules. In one such case, the Court had stated, "This right of the states to regulate and

30. Lyon, 29 Cal. 3d at 226, 229, 625 P.2d at 248, 250, 172 Cal. Rptr. at 705, 707.

31. Id. at 227, 625 P.2d at 249, 172 Cal. Rptr. at 706 (quoting City of Berkeley v. Superior Court, 26 Cal. 3d 515, 521, 606 P.2d 362, 365, 162 Cal. Rptr. 327, 330 (1980)).

32. The same doctrine as to the dominion and sovereignty over and ownership of lands under the navigable waters of the Great Lakes applies, which obtains at the common law as to the dominion and sovereignty over and ownership of lands under tide waters on the borders of the sea, [these] lands are . . . subject to the same trusts and limitations. IIlinois Central, 146 U.S. at 437.

33. The Court noted: "The Great Lakes are not in any appreciable respect affected by the tide, and yet on their waters, as said above, a large commerce is carried on, exceeding in inany instances the entire commerce of States on the borders of the sea." Id. at 436.

34. Id. at 452-53. This particular grant consisted of over 1000 acres of land extending for one mile out from the shore of Lake Michigan and representing the entire outer larbor of Chicago. Id. at 438 . 
control the shores of tidewaters and the land under them, is the same as that which is exercised by the Crown in England. In this country the same rule has been extended to our great navigable lakes, which are treated as inland seas."35 Because of its commercial significance, Lake Michigan was viewed as one such inland sea. ${ }^{36}$ In treating it as a tidal body of water whose bed was subject to the public trust, the Illinois Central Court followed a narrow precedent. Thus, the case did not establish a rule that the public trust applies to the beds of all navigable waters.

Furthermore, the Lyon court's expansive interpretation of Illinois Central as mandating a federal common law trust is inconsistent with the many cases holdimg that each state determines for itself the extent and nature of its trust interests. ${ }^{37}$ Cases dealing with the imterests of riparian owners arising shortly before ${ }^{38}$ and after $^{39}$ Illinois Central were decided on the basis of state law. Illinois Central is consistent with these cases when it is viewed as an application of Illinois state law.

Illinois law treated the Great Lakes as a special case: it classified the bed of Lake Michigan as trust property because it was functionally equivalent to a tidal sea. ${ }^{40}$ Illinois later classified the beds of all lakes as trust property, ${ }^{41}$ but chose not to extend the same treatment to waters with currents. For example, a grant of land on the Mississippi River to a private owner conveyed an absolute fee to midstream. ${ }^{42}$ That the Uinited States Supreme Court recognized the validity of such grants only one year before Illinois Central ${ }^{43}$ demonstrates that state law controlled the extent of the public trust. ${ }^{44}$

The final problem with the Lyon court's view of Illinois Central is that the court failed to take account of the difference between submerged lands ${ }^{45}$ and the shorezone between high and low water mark. In Illinois Central, submerged lands and the shorezone were treated differently. The Supreme Court allowed the legislature to revoke the grant of the submerged lands, but the railroad was permitted to keep its

35. Hardin v. Jordan, 140 U.S. 371,382 (1891).

36. Id. at 386.

37. See supra notes 19-21 and accompanying text.

38. Hardin v. Jordan, 140 U.S. 371 (1891).

39. Shively v. Bowlby, 152 U.S. 1 (1894).

40. Seaman v. Smith, 24 Ill. 521 (1860).

41. Trustees of Schools v. Schroll, 120 Ill. 509, 12 N.E. 243 (1886).

42. See St. Louis v. Rutz, 138 U.S. 226, 242 (1891).

43. Id.

44. Even the Lyon court accepted the Supreme Court's later affirmation that Illinois Central was "necessarily a statement of Illinois law." Lyon, 29 Cal. 3d at 229 n.16, 625 P.2d at 259 n.16, 172 Cal. Rptr. at 707 n.16 (quoting Appleby v. City of New York, 271 U.S. 364, 395 (1926)).

45. Submerged lands are below water all of the time. They are "lands seaward of the line of mean low tide." City of Long Beach v. Mansell, 3 Cal. 3d 462, 478 n.13, 476 P.2d 423, 434 n.13, 91 Cal. Rptr. 23, 34 n.13 (1970). 
interest in the shorezone. ${ }^{46}$ The Court's only concern with regard to the shorezone was whether the railroad's piers and docks might extend so far from the shore as to interfere with navigation. ${ }^{47}$ Since the Court did not address the issue of whether the public trust applied to the shorezone, the case does not provide any authority on this point.

However, a later case, Massachusetts v. New York, ${ }^{48}$ nakes it clear that federal law does not create public trust rights in the shorezones of nontidal waters. The case involved a New York grant of riparian land on the Great Lakes to Massachusetts and a reconveyance by Massachusetts to private grantees. The United States Supreme Court established a strong presumption that New York had not relinquished its rights as trustee of the submerged bed of Lake Ontario, ${ }^{49}$ but adopted an opposite presunption regarding shorezone ownership. ${ }^{50}$ The Court stated that, in the absence of express state law, "there are no public rights in the shores of non-tidal waters." tabhish a trust in the submerged beds of nontidal waters this trust would not necessarily extend to the shorezone.

The foregoing analysis of Illinois Central shows that the case cannot stand for a general proposition that every state lias a federally niandated public trust in all freshwater shorezones. That case was decided on the basis of Illinois law, and its loolding was limited to the subnerged beds of the Great Lakes. Only an inquiry into California law can determine the boundaries of California's public trust doctrine.

\section{Scope of California's Public Trust Before Lyon}

Prior to Lyon, there was no indication in California statutes or case law that shorezones were subject to the public trust. The existence of the tidelands trust did not necessarily imply a public trust for shorezones. In fact, shorezones and tidelands have been liandled differently under California law.

Divergent treatment of tidelands and shorezones is found in California Civil Code section 830, which defines the ownership interests of

46. 146 U.S. at $445-53$.

47. Id. at $450-51,464$.

48. 271 U.S. 65 (1926).

49. The dominion over navigable waters, and property in the soil under them, are so identified with the exercise of the sovereign powers of government that a presumption against their separation from sovereignty must be indulged, in construing all grants by the sovereign, of lands to be held in private ownership.

Id. at 89 .

50. There is no conceivable purpose for which it could be supposed that Massachusetts intended to retain such a proprietary interest in the shore as is now claimed. . . . We are not dealing here with the disposition of the jus publicam, but with land held by Massachusetts in private ownership and granted by it to private persons.

Id. at 91-92.

51. Id. at 93 . 
individuals. Section 830 states that unless a grant states otherwise, the upland owner takes title to the low water mark when his land borders on a navigable lake or stream..$^{52}$ Therefore, the upland owner owns the shorezone. A grantee bordering on tidal waters takes title only to the high water mark ${ }^{53}$ and therefore does not own the tidelands. These rules are reinforced by section 670 , the reciprocal statute describing the state's ownership interest. ${ }^{54}$ According to the statute, the state owns subinerged lands underlying both tidal and nontidal navigable waters and also owns the tidelands, but does not own the shorezones.

In the absence of law to the contrary, California Civil Code sections 830 and 670 create a presumption that trust interests and ownership interests are coextensive-in other words, that only state-owned land is subject to the public trust. This conclusion is supported by Pubhic Resources Code section 6301, which omits shorezones from the list of trust lands administered by the State Lands Commission. ${ }^{55}$ It is also supported by the United States Supreine Court's decision in Barney v. Keokuk. There, the Court held that a state's choice of ownership rights determined its trust interest. Observing that many states liad chosen not to claim ownership of the beds and shorezones of navigable nontidal waters, the Court stated: "If they choose to resign to the riparian proprietor rights which properly belong to them in their sovereign capacity, it is not for others to raise objections." 56 The rights spoken of are the state's rights as trustee, since these are the only rights that the state has in such property. ${ }^{57}$ The Barney Court assumed that conveying the land would inean relinquishing these rights.

However, ownership rights and trust rights are not always coextensive in California. Before the 1909 legislative ban on the sale of tidelands, ${ }^{58}$ the state granted sonie tidelands to private owners. Nevertheless, it has consistently asserted public rights in those lands. In these cases, ownership rights are private, but trust rights are retained by the public - the two are not coextensive. The Lyon court relied on this exaniple when it imposed the trust on privately owned sliorezones, but its rehance was misplaced. Since the 1909 ban, trust interests have followed the ownership interests defined in Civil Code sections 830 and 670: the state now owns all (ungranted) trust lands. However, neitler

52. CAL. CIv. CODE $\$ 830$ (West 1954).

53. $I d$.

54. Id. $\$ 670$.

55. CAL. Pub. Res. CODE $\S 6301$ (West 1977).

56. Barney v. Keokuk, 94 U.S. at 338.

57. The state took title to the beds of navigable waters not in its proprietary capacity, but as trustee. City of Berkeley, 26 Cal. 3d at 521, 606 P.2d at 365, 162 Cal. Rptr. at 330.

58. CAL. PuB. Res. CODE $\$ 7991$ (West 1977) (originally enacted as Act of March 25, 1909, ch. 444, 1909 Cal. Stat. 774). 
statute indicates any state interest in shorezones, which have always been and continue to be privately owned.

California cases that speak of trusts for nontidal waters fall far short of establishing that the state reserved a trust interest in the shorezone, and in fact suggest the contrary. The first case to declare that California had a trust interest in all subinerged beds, whether of tidal or nontidal water, was People v. Gold Run D. \& M. Co. ${ }^{59}$ There, the court enjoined a riparian owner from dumping mining debris into a navigable river because the activity was raising the river's bed and impeding navigation. The holding protected only the subinerged bed of the river, which was owned by the state. No issue was raised regarding the compatibility of the mining operations on the river bank with any trust interest. ${ }^{60}$

In People ex. rel. Baker v. Mack and Hitchings v. Del Rio Woods Recreation \& Park District, cases concerned with whether nontidal waters were within the definition of navigability and thus subject to public uses, ${ }^{61}$ there are also references to a trust interest. ${ }^{62}$ However, these cases only show that the trust has been applied to the submerged beds of nontidal waters, ${ }^{63}$ an apphication consistent with the state's ownership interest.

The clearest distinction between the treatınent of subinerged lands and shorezones is in Bohn v. Albertson. ${ }^{64}$ Bohn decided the rights of the owner and of the public in a flooded area. The court of appeal acknowledged the public right to the use of navigable waters, including "the incidental use of the bottoin" for such purposes as wading, boat-

59. The rights of the people in the navigable rivers of the State are paramount and controlling. The State holds the absolute right to all navigable waters and the soils under them. . . . The soil she holds as trustee of a public trust for the benefit of the people; and she inay, by her legislature, grant it to an individual; but she cannot grant the rights of the people to the use of the navigable waters flowing over it; these are inalienable. Any grant of the soil, therefore, would be subject to the paramount rights of the people to use the highway.

66 Cal. 138, 151-52, 4 P. 1152, 1159 (1884).

60. Id. at $147,4 \mathrm{P}$. at $1155-56$.

61. Under the California Constitution and under the common law, there are public rights of access and use in all waters that are navigable in fact. CAL. Const. art. X, § 4; Wright v. Seymour, 69 Cal. 122, 125, 10 P. 323, 325 (1886).

62. Baker referred to California's "sovereignty and jurisdiction over navigable waters and lands underneath them." 19 Cal. App. 3d 1040, 1050, 97 Cal. Rptr. 448, 454 (3d Dist. 1971). Hitchings declared that "the state has absolute power to control, regulate and utilize navigable waters within the terms of its public trust." 55 Cal. App. 3d 560, 572, 127 Cal. Rptr. 830, 837 (Ist Dist. 1976).

63. Hitchings distinguished between the absolute public right to use the Russian River (and presumably its submerged bed) for recreational purposes, and the separate public rights in the shorezone beacls and parking lot, which existed in that particular case only because the upland property happened to be owned by a public entity, namely the park and recreation district. 55 Cal. App. 3d at 572, 172 Cal. Rptr. at 838.

64. 107 Cal. App. 2d 738, 238 P.2d 128 (Ist Dist. 1951). 
ing, and casting anchor. The public rights in the shorezone, however, existed only while it was flooded. The owner could at any time drain the flooded shorezone lands and assert his private rights to exclusive use and occupation..$^{65}$

In summary, Civil Code sections 830 and 670 and Public Resources Code section 6301 create a strong presumption that California chose to make ownership rights and trust rights in lands underlying nontidal waters coextensive and thus to limit the trust to submerged lands. ${ }^{66}$ This interpretation is not contradicted by what little case law there is on the subject. Therefore, the Lyon dissent was correct in stating that the court was imposing a trust on the shorezone for the first time. ${ }^{67}$

\section{Evolution of Public Trust Purposes}

It was the evolution of trust purposes that motivated the Lyon court to extend the public trust to the shorezones of nontidal waters. During the century that the trust was seen as protecting solely commercial navigation and fishing, only tidelands were subject to the trust. Tidelands were much more useful for the traditional purposes than were shorezones. However, as trust purposes expanded to include recreational uses and environmental protection, rivers and lakes becaine prime candidates for apphication of the public trust doctrine.

The public trust was origmally developed to protect the public use of the waters for either commercial navigation or fishing. Historically, it has been only a tidelands trust for several reasons. First, tidelands are under water for part of each day as part of the submerged bed of the sea. Shorezones are dry lands much of the time and are therefore less closely connected with water use. Second, because of their high salt content, tidelands cannot be used for many purposes other than those incident to navigation. Hence, in inost cases, the trust purposes

65. Id. at 749, 238 P.2d at 135-36. See Note, California Civil Code Section 830: A Rule of Property Needed for the Protection of the Private Landowner, 9 PAC. L.J. 1011, 1024-28 (1978).

66. Lyon argued that, despite their use of trust language, the California cases create not a trust interest, but merely a navigational easement for the benefit of the publie. Since, under a navigational easement, the public has no right to use the dry shorezone area, Lyon's proposed analysis yields the same practical results as the present argument that the trust interest extends ouly to submerged beds. For a discussion of the navigational easement cases, see Note, supra note 65 , at $1024-26$.

67. The Lyon majority referred to the ouly previous mention of a shorezone trust, although the referenced source lacks precedential value. When he was attorney general, Justice Mosk, author of the Lyon decision, wrote an opinion stating that the government inay permit private ownership of land on nontidal waters to low water mark "as long as the rights of the public are not impaired." 45 Op. Att'y Gen. 291, 294 (1964). The opinion, which acknowledged that sucl rights are a matter of state law, assumed that California had asserted a trust interest in the shorezone. As we have seen, this was not the case. 
of navigation and fishing were consonant with the best use of tidelands. ${ }^{68}$

When tidelands could be used for other purposes, the scope of the trust could be reduced. Early in its history, California adopted the rule that the state could terminate the trust in tidelands that were valuable for agriculture and were not useful for navigational purposes. ${ }^{69}$ Even where tidelands were useful for trust purposes, the state sold them when they were needed for agriculture. ${ }^{70}$

Because they lay along freshwater bodies, shorezones were much better suited to agricultural and residential use. The state, then, had hittle incentive to impose the trust on shorezones, which were useful for nontrust purposes.

Finally, as long as trust purposes were restricted to protecting coinmercial navigation, the shorezones of many nontidal bodies of water were not likely targets for imposition of a public trust. ${ }^{71}$ Most nontidal bodies of water simply were not important for the original trust purposes. Waters such as Clear Lake and Lake Tahoe, which were the subjects of Lyon and Fogerty, are important primarily for recreational use.

In recent years, the scope of trust purposes has expanded to include recreational navigation and preservation of the environment. Several cases established that the public had rights in waters that could be used for recreational boating. ${ }^{72}$ In Marks $v$. Whitney, ${ }^{73}$ trust purposes were expanded to include environmental protection. The California Supreme Court held that preservation of tidelands in their natural state had becoine important enough to be a public use encompassed by the public trust. ${ }^{74}$ The court found that the tidelands could serve as ecological units for scientific study, as open space, and as envi-

68. One commentator, describing the origins of the public trust doctrine in England, stated that tidelands are "incapable of ordinary and private occupation, cultivation and improvement. Hence the title . . . in such lands belonged to the King as the sovereign, but . . . was subject to the public right . . of navigation and fishing." A. Shalowitz, SHORe AND SEA Boundaries 9091 (1962). See also Comment, Fluctuating Shorelines and Tidal Boundaries: An Unresolved Prob. lem, 6 SAN Diego L. Rev. 447, 456 (1969) ("The primary consideration was to make the most practical and efficient use of the land. The only land considered capable of being used was land above the line of the ordinary tides.").

69. Ward v. Mulford, 32 Cal. 365,373 (1867).

70. Califomia Fish, 166 Cal. at 591-92, 138 P.2d at 85-86.

71. Early statements concerning application of the public trust to nontidal waters naturally appeared in connection with rivers of commercial importance. For example, in Gold Run, the Sacramento River was described as a "great public highway." 66 Cal. at 146, 4 P. at 1155.

72. Hitchings v. Del Rio Woods Recreation \& Park Dist., 55 Cal. App. 3d 560, 127 Cal. Rptr. 830 (1st Dist. 1976); People ex rel. Baker v. Mack, 19 Cal. App. 3d 1040, 97 Cal. Rptr. 448 (3d Dist. 1971).

73. 6 Cal. 3d 251, 491 P.2d 374, 98 Cal. Rptr. 790 (1971).

74. Id. at 259, 491 P.2d at 380, 98 Cal. Rptr. at 796. 
ronments that provide food and habitat for birds and marine life. ${ }^{75}$

Once the focus of the trust shifted from commercial navigation to recreational, aesthetic, and ecological concerns, shorezones became as important to the state as tidelands. The Marks $v$. Whitney rationale for protecting the tidelands environment applies equally well to the shorezones. By expanding the range of trust purposes for the tidelands trust, the California Supreme Court paved the way for the Lyon decision to subject the shorezones to the public trust. Thus, the history of trust purposes serves to explaim both why sliorezones were not included in the trust earher and why they are now included.

\section{B. Fogerty and the Trust Purpose of Preservation}

In Fogerty, the plaintiff argued that even if shorezones were trust property equivalent to tidelands, the state should still be barred from asserting this trust interest because of its misleading conduct-it had given owners of shorezone property no indication that any imterest had been retained. The court rejected this estoppel argument on the basis that the public interest in environmental preservation was paramount. In doing so, it failed either to weigh the interests of the private owners or to consider whether the environment would actually be protected by the trust. A proper balancing of all interests demonstrates that the state should have been barred from imposing the public interest on shorezones.

\section{The Mansell Balancing Test}

The Fogerty court's refusal to grant equitable relief was based on its misimterpretation of City of Long Beach v. Mansell, ${ }^{76}$ the leading case on applying estoppel against the state. Mansell involved very complicated questions regarding the boundaries of uplands and tidelands, all of which had been filled and developed. The owners and the state had made an agreement that freed some of the tidelands from the public trust. This agreement violated the California constitutional prohibition against alienation of tidelands within two miles of a city. The court held that the prohibition could not be used to defeat the agreement and reinstate the trust. The land had been filled and improved with the knowledge and acquiescence of both the state and city, and the estoppel was granted.

Although Mansell was a case in which estoppel was granted, the Fogerty court rehed on its statement that "estoppel will not be applied against the government if to do so would effectively nullify a strong

75. Id.

76. 3 Cal. 3d 462, 476 P.2d 423, 91 Cal. Rptr. 23 (1970). 
rule of policy adopted for the benefit of the public."77 The Fogerty court then denied the estoppel, pointing to the state's environmental policy interest in asserting the shorezone trust. As pointed out by the Fogerty dissent, however, Mansell held that governmental bodies could be estopped when the injustice of the potential liarm to the private party outweighed any harm to the public interest. ${ }^{78}$ The Fogerty court did not weigh the opposing private interests involved and therefore failed to apply the balancing test established in Mansell $^{79}$

\section{The Test Applied to Fogerty}

Application of the Mansell balancing test to the shorezone cases requires a two-stage analysis. The first inquiry concerns the harm to private owners caused by the imposition of the trust. The second involves the extent to which the trust will actually further the goal of environmental protection. In a case like Fogerty, these considerations tip the balance against the imposition of the trust.

Froin the viewpoint of the landowner, the public trust, conipared with other environmental protection measures, is an extren1ely harsl1 means of land use regulation. Environmental regulation is usually limited to preventing the owner from taking actions that have a negative impact on the environment, but the public trust is much broader. Under a trust regime, land can be dedicated to public use for whatever purpose the State Lands Commission deems appropriate. ${ }^{80}$ For example, the state may require that the private owner allow public use of the land for hunting, fishing or recreation. ${ }^{81}$ Thus, the trust imposes an additional burden even on an owner like Fogerty, who wants to preserve his land ${ }^{82}$ in accordance with the purposes of environmental regulation. For an owner like Lyon, who wants to fill and develop his land, the trust is also inore onerous than environmental regulation, which unlike the trust cannot deny him all use of his land by requiring that it be preserved in its natural state. ${ }^{83}$

For both owners, the imposition of the trust is a disability; it places

77. Id. at 493,476 P.2d at 445,91 Cal. Rptr. at 45 .

78. Id. at $496-97,476$ P.2d at 423,91 Cal. Rptr. at 23.

79. The Mansell court stressed that it was creating an "extremely narrow precedent for application in future cases." Id. at 500 . However, the anticipated rarity of circumstances that would enable the private owner to prevail against the state does not obviate the need to apply the balancing test in a particular case.

80. Cal. Pub. Res. Code $\S 6301$ (West 1977). Apparently, the State Lands Commission would be the administrator of all trust lands, although its jurisdiction under this section is limited to tidelands and submerged lands.

81. See infra note 112.

82. Part of Fogerty's argument was that the private owner would do a better job of preserving the shoreline than the state would. 29 Cal. 3d at 246, 625 P.2d at 260, 172 Cal. Rptr. at 717.

83. See infra text accompanying notes $96-100$. 
a permanent cloud on the title to their lands. Unlike land use regulations, which may be amended or repealed and under which variances may be granted, the public trust is extremely difficult to terminate. Traditionally, the state interest in trust property could be extinguished only if the grant to the private party was in aid of navigation. If the grant was not in accordance with this limited purpose, property widely assumed to be held in fee simple could be subjected to the trust decades later. ${ }^{84}$ Only when such land has been rendered useless for trust purposes by filling and developinent has the court been willing to terminate the trust. ${ }^{85}$

Moreover, imposing the trust will not necessarily further the goal of environmental protection, because trust purposes are diverse and even contradictory. The Fogerty court assumed, as did environmental organizations, ${ }^{86}$ that the imposition of the trust would have the effect of preserving affected areas in their natural state. The public trust doctrine, however, does not mandate any particular use of the lands. The only requirenent is that the permitted use fall within a defined purpose of the trust. Even when the trust was limited to the traditional purposes of navigation, commerce, and fisheries, these trust purposes were interpreted broadly to allow the state to implement public projects that were only tangentially related to water use. ${ }^{87}$ Thus, housing for merchant seamen, ${ }^{88}$ bridges that actually impeded navigation, ${ }^{89}$ and garish coininercial development ${ }^{90}$ have all been upheld as proper uses of tideland

84. California Fish, 166 Cal. at 585,138 P. at 82-83.

85. Mansell, 3 Cal. 3d 462, 476 P.2d 423, 91 Cal. Rptr. 23 (1970), illustrates the difficulties of terminating the trust even where trust lands have been so developed as to be useless for trust purposes. See supra note 76 and accompanying text. See also City of Berkeley, 26 Cal. 3d at 534, 606 P.2d at 373, 162 Cal. Rptr. at 338.

86. Amicus briefs were filed by the Department of Water Resources, Sierra Club, Natural Resources Defense Council, Audubon Society, and Friends of the Earth.

87. See generally Sax, supra note 24 , at 538-46.

88. People v. City of Long Beach, 51 Cal 2d 875, 338 P.2d 177 (1959) (construction on tidelands of a Y.M.C.A. to house merchant seamen and others engaged in navigation, commerce, and fishery held to be within purposes of trust).

89. Colberg, Ine. v. State, 67 Cal. 2d 408, 432 P.2d 3, 62 Cal. Rptr. 401 (1967). The state's erection of bridges that actually impeded navigation by water was held to be within the scope of trust purposes. In adopting this view, the court stated that trust purposes have been construed biberally so that the state has flexibility in determining which uses best serve the general welfare. Id at 417, 422, 432 P.2d at 9, 12, 62 Cal. Rptr. at 407, 410.

90. Martin v. Simith, 184 Cal. App. 2d 571, 578, 7 Cal. Rptr. 725, 728 (1st Dist. 1960). A city's lease of its tidelands for development of a motel, restaurant, shops, and swimming pool was held to be "consistent with the trust upon which such lands were conveyed to the city, and with the requireinents of commerce and navigation of said harbor."

Use of tidelands for exploitation of mimeral resources has been rationalized for decades. City of Long Beach v. Marshall, 11 Cal. 2d 609, 620, 82 P.2d 362, 367 (1938); Boone v. Kingsbury, 206 Cal. 148, 181, 273 P. 797, $811-12$ (1928). As recently as 1980, a California court said with regard to the leasing of tidelands for the production of oil and gas: "There is of course no trust prohibition on leasing. As noted, the state, acting through the [State Lands] Commission, may lease tidelands 
trust property.

The expansion of public trust purposes to include preservation means only that preservation is among the sanctioned uses of trust lands, not that this is necessarily the use to which trust lands will be subjected. ${ }^{91}$ The Fogerty court created no guidelines for the selection of trust purposes and had no power to do so. The selection of trust purposes is within the sole discretion of the State Lands Commission. ${ }^{92}$ By imposing the trust on shorezones, the court inerely establislied a doctrine that would obviate the need for compensation should the preservation purposes be chosen.

Any other land use regulation enforcing preservation without compensation would be subject to attack as an unconstitutional taking. The imposition of trust purposes on shorezones should be vulnerable to the charge of taking as well.

\section{The Missing Issue: Unconstitutional Taking of Property}

The Lyon and Fogerty courts, by asserting that public rights liad always existed in nontidal shorezones, were able to evade the issue of whether imposition of the trust caused private property to be taken for public use without the just compensation required by the federal and state constitutions. ${ }^{93}$ No issue of a taking arises when the state subjects trust lands to trust uses. ${ }^{94}$ It could of course be argued that the Marks expansion of trust purposes to include preservation is a taking in itself even with regard to lands that have always been subject to the trust. The preservation purpose is particularly controversial because it can prevent all use of land and because it is not directly related to water use. But given the variety of projects that liave been held to be within the trust and the necessarily limited expectations of an owner of known trust land, the expansion of trust purposes to include preservation of

under terms and conditions it determines to be in the best interests of the state." Western Oil \& Gas Ass'n v. State Lands Comm'n, 105 Cal. App. 3d 554, 563, 164 Cal. Rptr. 468, 473 (3d Dist. 1980). The case arose in the unusual posture of a suit by the oil companies against the state on the theory that the latter was unpeding commerce by charging unreasonably high rentals on leases of tidelands.

91. See, e.g., County of Orange v. Heim, 30 Cal. App. 3d 694, 106 Cal. Rptr. 825 (4th Dist. 1973) (citations omitted):

It is argued in counection with several issues that the Plan is not the best plan that could be devised from the public standpoint and, even that the UNB, or at least portions thereof, ought not to be developed as a recreational harbor but ought to be preserved in its natural state. These are not matters to be decided by the courts. While the preservation of tidelands in their natural state is now recognized as a use encompassed in the tidelands trust purposes, it is the Legislature that administers the trust, and it is within the province of the Legislature to prefer one trust use over another.

92. Cal. Pub. Res. Code $\S 6301$ (West 1977).

93. U.S. CoNST. amend. V; CAL. ConsT. art. I, § 19.

94. Colberg, 67 Cal. 2d at 420, 425, 432 P.2d at 11, 14, 62 Cal. Rptr. at 409, 412. 
lands already within the trust is probably not a taking. However, when land is suddenly redefined as trust property and is required to be preserved in its natural state or is subjected to other public use, the typical taking issues do arise. ${ }^{95}$

\section{Preservation}

Government regulations that further important public policies may amount to a taking, which requires compensation. ${ }^{96}$ The test is whether an otherwise valid regulation leaves an owner an "economically viable use of his land."97 Land use regulations that merely diminish the value of land do not constitute a taking. ${ }^{98}$ Thus, in Agins v. City of Tiburon, the United States Supreme Court upheld agamst a constitutional challenge an open-space zoning ordinance that clearly diminished the value of the land but still allowed the owner to build up to five houses on his five-acre tract. ${ }^{99}$ The Court did not define the point at which an open-space regulation would deny the owner all economic use. Instead, it left open the question of "whether the zoning ordinance would be unconstitutional if apphed to prevent appellants from building [fewer than] five homes." 100

Similarly, the Supreme Court refused to find a taking in Penn Central Transportation Co. v. New York City. ${ }^{101}$ There, a city agency had designated Grand Central Terminal an historical landmark, thereby preventing the erection of a skyscraper above the station. The Court predicated its holding on the grounds that the regulation (1) did not interfere with the owners' present use; (2) would allow some further development of the property; and (3) allowed the owners to transfer their development rights to other property, which was a form of indirect compensation. ${ }^{102}$ Thus, while governmental bodies have wide discretion to regulate land use, they must allow owners some freedom to enjoy their property or provide sonie form of compensation.

95. It may be argued that the taking issue was not ripe for discussion in Lyon and Fogerty because no particular trust use had yet been selected. Nevertheless, simce the court assumed that preservation would be the goal, it should have considered the constitutional consequences. The Fish and Game Commission had already demed Lyon a permit to develop his marsh; the Lyon opinion did not change that result. Cf. Dahl v. City of Palo Alto, 372 F. Supp. 647,649 (N.D. Cal. 1974) (noting that the court will assume that all permits will be denied where a "goal of preserving the land in its natural or near natural state" has been adopted).

96. Pennsylvamia Coal Co. v. Mahon, 260 U.S. 393, 415 (1922).

97. Agins v. City of Tiburon, 447 U.S. 255, 260 (1980).

98. HFH Ltd. v. Superior Court, 15 Cal. 3d 508, 518, 542 P.2d 237, 244, 125 Cal, Rptr. 365, 372 (1975).

99. Agins, 447 U.S. at 260.

100. Id. at 260 .

101. 438 U.S. 104 (1977).

102. Id. at 136-38. The Court did, however, affirm its holding of Pennsylvamia Coal Co. v. Mahon, 260 U.S. 393 (1922). 
It is clear that the extent to which any governmental body may cause the devaluation of private land is limited. In the recent case of San Diego Gas \& Electric Co. v. San Diego, ${ }^{103}$ a California appellate court found that a taking had occurred when the city placed the plaimtiff's land in an open-space zone created for environmental purposes. ${ }^{104}$ The court found that this ordinance prevented all practical use of the property and that therefore coinpensation was required. ${ }^{105}$ The California Supreine Court, however, vacated the opinion on the ground that invalidation of an oppressive ordinance was a landowner's sole reinedy. ${ }^{106}$

The plaintiff appealed to the Umited States Supreine Court, whicl1 held that it lacked jurisdiction to consider the case because no final judgment granting or denying invalidation had been rendered im California state courts. ${ }^{107}$ Justice Rehnquist imdicated in his concurrence that he would have voted with the four dissenters had a final state judgment been rendered. ${ }^{108}$ Thus, the Court was only a procedural hurdle away froin adopting the dissent's position that just compensation must be paid to an owner when preservation regulations "completely deprive the owner of all or nost of his interest in the property." 109

The dissent gave short shrift to the policy considerations that have led states to attack environmental problems through preservation regu-

103. 146 Cal. Rptr. 103 (4th Dist. 1978), officially depublished pursuant to CAL. CT. R. 976(d) (West 1982).

104. Like San Diego, the Lyon case involved a situation in which the state intended to purchase the owner's land and only later decided that the imposition of the trust would inake this step unnecessary.

105. Here there was evidence [that the] Company could not develop this land in any way.

This is more than just decreasing the value of the land; it is destroying it completely .... There is no evidence of actual physical invasion of the property. However, this is exactly what the City is trying to do by acquiring the property, that is, keep [it] undisturbed and in its natural state so open space and scenic vistas may be preserved. In this sense the property is being "used" by the public.

146 Cal. Rptr. at 117.

106. The California Supreme Court had leld that invalidation of an oppressive ordinance was the owner's sole remedy. Agins v. City of Tiburon, $24 \mathrm{Cal}$. 3d 266, 276-78, $598 \mathrm{P} .2 \mathrm{~d} 25,29-31$, 151 Cal. Rptr. 372, 376-78 (1979), aff'd, 447 U.S. 255 (1980). Therefore, the San Diego opinion was vacated, and the case was remanded to the appellate court, which, in an unpublisled opinion, failed to reach a conclusion as to whether the ordinance should be invalidated due to disputed factual issues that bore on the applicability of the invalidation remedy. See San Diego Gas \& Elec. Co. v. City of San Diego, 450 U.S. 621, 627-30 (1981).

107. 450 U.S. at 630. On remand, the California Court of Appeal did not reacl a conclusion as to the availability of the invalidation remedy because relevant disputed factual issues-whether the city had arbitrarily exercised its police power by enacting or applying unconstitutional zoning or planning elements - had to be resolved at the trial court level.

108. Id. at 633-34 (Rehnquist, J., concurring). The dissent reached the merits because it found the appellate court's holding on remand (that regulation could never give rise to a taking for which compensation could be compelled) a final decision subject to review. Id. at $639-46$ (Brennan, J., dissenting).

109. Id. at 653. Note that just compensation may include interim damages. 
lations which place burdens on private owners and avoid state financial liability. Writing for the dissent, Justice Brennan stated that "[t]he apphicability of express constitutional guarantees is not a matter to be determined on the basis of policy judgments made by the legislative, executive, or judicial branches."110 Although lacking in precedential value, the dissenting opinion clearly indicates that, in the view of the majority of the justices, a state wishing to preserve land for environinental purposes must compensate the owners. Hence, if Justice Rehnquist and the dissenters im San Diego adhere to their view on this issue, there may be a need to coinpensate owners of shorezones newly subjected to the public trust.

\section{Public Use}

Subjecting sliorezone lands to public use raises the issue of an unconstitutional taking even more certainly than preservation regulation does. As noted earlier, the taking issue would not arise if actual trust property were involved. ${ }^{11}$ It is well established in the law that trust lands can be subjected to actual use by the public without compensation. Thus, in Forestier $v$. Johnson, ${ }^{112}$ the right of the public to enter upon privately owned tidelands for the purposes of hunting and fishing was upheld. Marks $v$. Whitney ${ }^{113}$ is the modern case validating the use of privately owned trust property for public recreation. ${ }^{114}$

However, actual physical mvasion of private nontrust property clearly gives rise to a constitutional right to compensation. ${ }^{115}$ The Supreme Court recently noted in Kaiser Aetna v. United States that "confiscation may result from a taking of the use of property without compensation quite as well as from the taking of the title."116 It then held that compensation was rcquired for the acquisition of public use rights in a private pond that was connected to navigable waters. ${ }^{117}$

Despite the rule that a public entity cannot employ land use regulation to subject private property to public use without payinent, ${ }^{118}$

110. Id. at 661 .

111. See supra note 94.

112. 164 Cal. 24, 127 P. 156 (1912).

113. 6 Cal. 3d 251, 491 P.2d 374, 98 Cal. Rptr. 790 (1971).

114. See also Sax, supra note 24, at 529: "It is clear that so long as the [trust] land or water overlying it is still physically suitable for public use, the owner may not exclude the public-lie may not fence his land or eject the public as trespassers."

115. "Private property may be taken or damaged for public use only when just compensation has first been paid . . . " CAL. Const. art. I, \& 19.

116. 444 U.S. 164, 174 n.8 (1979) (quoting Chicago, R.I. \& P. Ry. v. United States, 284 U.S. $80,96(1931))$.

117. Id. at $178-80$.

118. HFH Ltd. v. Superior Court, 15 Cal. 3d 508, 517 n.14, 542 P.2d 237, 243 n.14, 125 Cal. Rptr. 365, 371 n.14 (1975). 
government entities have continually tried to avoid payment for public rights. The acquisition of public rights in California ocean beaches is instructive. ${ }^{119}$ Unlike shorezone rights, the private nature of which had never been questioned prior to Lyon and Fogerty, the public's rights im privately owned beaches has been litigated frequently in recent years. The cases demonstrate that the state has been able to avoid the general requirement of compensation only through the application of special rules for implied dedication and subdivision exactions.

For example, Gion v. City of Santa Cruz held that private beach property had been dedicated to public use when a substantial segment of the public used the land with the knowledge and without the objection of the owner for more than five years. ${ }^{120}$ This requirement for dedication would rarely be met in shorezone cases because public rights in recreational nontidal waters are of recent vintage.

Subdivision exactions comprise the other context in which Califorma has been able to subject nontrust private beach property to public use without compensation. The requirement that a developer dedicate land to the public as a condition for approval of his subdivision map ${ }^{121}$ was held constitutional in Associated Home Builders, Inc. v. City of Walnut Creek. ${ }^{122}$ In Natural Resources Defense Council, Inc. v. California Coastal Zone Conservation Commission, the requirement of public access to otherwise private beaches was upheld as the price of constructing a housing development along the California coast. ${ }^{123}$ Similarly, under the terms of a special legislative enactment, ${ }^{124}$ the Northern California Sea Ranch development must dedicate an easement for public use of the beach above its tidelands. ${ }^{125}$

Recent developments in which private beaches have been sub-

119. The problem is that although public use of the tidelands is protected by the public trust, this area is not sufficient for public recreational opportunities; use of the dry sand area above the line of high tide is desirable. Comment, Public Beaches: A Reevalution, 15 SAN Diego L. Rev. 1241, 1242-43 (1978); Comment, Public Access 10 Beaches, 22 STAN. L. Rev. 564, 565-66 (1970). When this nontrust beach area is in private ownership, problems comparable to those involved in subjecting nontrust slorezones to public use arise.

120. 2 Cal. 3d 29, 44, 465 P.2d 50, 60, 84 Cal. Rptr. 162, 172 (1970). Subsequent decisions liave been based on whether they fit the Gion factual pattern. See, e.g., County of Los Angeles v. Berk, 26 Cal. 3d 201, 605 P.2d 381, 161 Cal. Rptr. 742 (1980); County of Orange v. ClrandlerSherman Corp., 54 Cal. App. 3d 561, 126 Cal. Rptr. 765 (4th Dist. 1976).

121. The mumicipality is permitted by statute to make this requirement. CAL. Gov't CoDE $\S 66477$ (West 1981).

122. 4 Cal. 3d 633, 484 P.2d 606, 94 Cal.Rptr. 630 (1971).

123. 57 Cal. App. 3d 76, 92, 129 Cal. Rptr. 57, 67 (1976).

124. Cal. Pub. Res. Code $\S 30610.6(6)$ (West 1981).

125. The developer had appealed an earlier ruling by the federal district court validating the subdivision exactions. In a summary disposition, the United States Supreme Court vacated the district court's judgment and remanded for reconsideration in light of CAI. PUB. REs. CODE § 30610.6. Sea Ranch Ass'n. v. Califormia Costal Comm'n, 102 S. Ct. 622 (1981) (menu.). 
jected to public use should not be confused with a change in the general law. It is of course true that, under current California law, if an owner of property adjacent to navigable waters is building a residential development, he may be required to dedicate public rights in the shorezone as the price of that development. However, in the absence of implied dedication or new development, the general rule will apply, and compensation will be required. Because the state did not reserve an interest in shorezones, they are privately owned land and should be treated like other privately owned land. State-imposed restrictions and burdens on shorezones, like those on other lands, should be tested as unconstitutional takings of property. The public trust should not be used to subject previously nontrust lands to public use without compensation.

\section{CONCLUSION}

In Lyon and Fogerty, the California Supreme Court for the first time imposed the public trust on privately owned shorezones. The decisions, which could be viewed as an attempted contribution to environmental protection, are not tenable on either legal or policy grounds. Because of the broad public uses to which trust lands may be subjected, the imposition of the trust will burden the private owner but give no assurance of effecting the court's goal of shoreline preservation. The public trust doctrine has a valuable flexibility in that trust property may be subjected to new uses as public purposes evolve, but its application to new lands has constitutional limits. The imposition of the trust on the shorezone is just as vulnerable to constitutional attack as other regulatory takings.

Janice Lawrence*

* B.A. 1963, Barnard College; M.A. 1965, Columbia University; third-year student, Boalt Hall School of Law, University of California, Berkeley. 